\title{
Recent advances on the characterization and control of sunflower soilborne pathogens under climate change conditions ${ }^{\text {th }}$
}

\author{
Leire Molinero-Ruiz ${ }^{*}$ \\ Institute for Sustainable Agriculture, CSIC, Alameda del Obispo s/n, 14004 Cordoba, Spain
}

Received 31 July 2018 - Accepted 16 August 2018

\begin{abstract}
The control of soilborne crop pathogens is conditioned by the limited management options due to difficult access to active infection courts and to restrictions in the use of synthetic pesticides in Europe. For most soilborne sunflower pathogens, an effective management relies on genetic resistance which is, however, hindered by new pathogen populations (new races). Special emphasis is thus put on updated monitoring and characterization of pathogens and on the enlargement of the set of tools for disease management. Concerning characterization, advances on the population structure of Verticillium dahliae affecting sunflower by means of genetic, molecular and pathogenic approaches are presented. Also in relation to increases of sunflower wilt diseases recently observed, the fungus Cadophora malorum has been identified in Russia and reported as a new pathogen of this crop. Third, new races of Plasmopara halstedii (sunflower downy mildew), have been identified in Spain and Portugal. Most of them have a high virulence, since they overcome several genes for resistance. With regard to alternatives for disease control, entomopathogenic fungi (EF) constitute a novel tool. Used for years in Integrated Pest Management strategies due to their efficacy in controlling insect pests affecting crops, new ecological roles of these fungi have recently been reported. The EF species Beauveria bassiana and Metarhizium brunneum have been assessed by their in vitro effect against $V$. dahliae and $C$. malorum by our research group. Our results suggest that antibiosis and/or competition for ecological niche are operating in some EF-pathogen interactions. In summary, pathogen characterization is essential for genetic resistance for worldwide environments of sunflower production. Moreover, the security of sunflower yield and profitability is dependent not only on effective genetic resistance, but also on additional new control options that can be included in successful strategies of sunflower disease management.
\end{abstract}

Keywords: biological control / genetic resistance / Helianthus annuus L / pathogenic races / soilborne fungi

Résumé - Avancées récentes sur la caractérisation et la lutte contre des agents pathogènes telluriques du tournesol en situation de changement climatique. La lutte contre des agents pathogènes telluriques des cultures est conditionnée par les options de gestion limitées en raison de l'accès difficile aux sites d'infection et aux restrictions dans l'utilisation des produits phytosanitaires de synthèse en Europe. Pour la plupart des agents pathogènes du tournesol présents dans le sol, une gestion efficace repose sur la résistance génétique, qui est toutefois entravée par de nouvelles populations de pathogènes (nouvelles races). Un accent particulier est donc mis sur la surveillance et la caractérisation actualisées des agents pathogènes et sur l'élargissement de l'ensemble des outils de gestion des maladies. En ce qui concerne la caractérisation, des avancées sur la structure des populations de Verticillium dahliae affectant le tournesol au moyen d'approches génétiques, moléculaires et pathologiques sont présentées. De plus, un nouveau pathogène du sol attaquant le tournesol, Cadophora malorum, a récemment été identifié en Russie. Troisièmement, de nouvelles races de Plasmopara halstedii (mildiou du tournesol) ont été identifiées en Espagne et au Portugal. La plupart d'entre elles présentent une virulence élevée, car elles surmontent plusieurs gènes de résistance. En ce qui concerne les alternatives de lutte contre les maladies, les champignons entomopathogènes (FE) constituent un nouvel outil. Utilisés depuis des années dans les

\footnotetext{
Contribution to the Topical Issue "Sunflower and climate change / Tournesol et changement climatique"

*Correspondence: Imolinero@ias.csic.es
} 
stratégies de lutte intégrée contre les ravageurs et les insectes en particulier, de nouveaux effets écologiques de ces champignons ont récemment été signalés. Les espèces EF Beauveria bassiana et Metarhizium brunneum ont été évaluées par notre groupe de recherche au regard de leur effet in vitro contre $V$. dahliae et C. malorum. Nos résultats suggèrent que l'antibiose et/ou la compétition pour la niche écologique interviennent dans certaines interactions entre agents pathogènes et EF. En résumé, la caractérisation des agents pathogènes est essentielle pour la résistance génétique dans les milieux de production de tournesol de par le monde. De plus, la sécurité du rendement et de la rentabilité du tournesol dépend non seulement d'une résistance génétique efficace, mais également de nouveaux moyens de lutte pouvant être inclus dans des stratégies efficaces de gestion des maladies du tournesol.

Mots-clés : lutte biologique / résistance génétique / Helianthus annuus L. / races pathogènes / champignons transmis par le sol

\section{Introduction}

Soilborne plant pathogens are carried on or beneath the soil surface, generally in the form of mycelia, spores and/or resting structures - such as sclerotia - which allow their survival under adverse conditions. Most of these pathogens (e.g. Pythium, Fusarium, Rhizoctonia) survive well as soil saprophytes while others are obligate parasites with a biotrophic habit of nutrition from their host and a very limited survival in its absence conditioned to the formation of resting structures, such as oospores in the case of oomycetes (e.g. Bremia, Plasmopara, Peronospora, Pseudoperonospora) (Schumann and D'Arcy, 2010) or dormant seeds in that of the noxious parasitic plants broomrapes (Orobanche and Phelipanche) (Molinero-Ruiz et al., 2015). Pathogen survival in the soil is a crucial trait particularly relevant in the implementation of Integrated Pest Management (IPM) of the diseases they cause. Management options are limited and hampered by difficult access to active infection courts (Chellemi et al., 2016), which are the sites of host/pathogen interface where infection takes place.

On the other hand, and from the point of view of phytopathology, climate change means adaptation to new conditions. In Figure 1, several factors influencing disease occurrence are represented. Host plant and pathogen are affected by the environment which, under global climate change conditions, is responsible for shifts. Some of these shifts can affect the host, such as new cultivation practices, the use of new crop genotypes (hybrids, open pollinated cultivars, etc.), or the emergence of new areas where particular crops can be grown. Among the factors directly related to plant pathogens we can mention more aggressive strains that, in some cases, can result in new races of pathogen populations, altered incidences of diseases (either increased or decreased) and even the evolution of cryptic and/or latent pathogens. Finally, we must consider that the emergence of new crops and/or new pathogens leading to unexpected diseases is also possible under change conditions associated with global change. In a world under conditions of changing (most frequently warmer) temperatures, pests and pathogens are expanding or re-distributing. Outbreaks of diseases caused by virus, fungi, bacteria and other plant pathogens are frequent and continuously reported all over the world (Bebber, 2015). Hot spots of new reports of crop pathogens between 2010 and 2015 obtained from ProMED email alerts (http://www.promedmail.org/) are widely distributed. They are located in Europe, Central America, East Africa, and Australia (Bebber, 2015).

Consequently, under situations of environmental shifts, continuous and updated monitoring and characterization of (sunflower soilborne) pathogens as well as the enlargement of the set of tools for efficient disease management must be emphasized.

\section{Monitoring and characterization of pathogens of sunflower}

\subsection{Plasmopara halstedii (Downy Mildew)}

The oomycete Plasmopara halstedii Farl. Berl. and de Toni causes downy mildew (DM) of sunflower, which is characterised by symptoms of stunting and leaf chlorosis. Chlorosis usually covers young leaves entirely but is limited to the area bordering the main veins of the lowest leaves. The disease is mainly controlled by means of genetic resistance, but pathogen races overcoming resistance genes in sunflower hybrids are often identified. Extensive research on pathogenic characterization of P. halstedii conducted between 1994 and 2006 resulted in the identification of nine different races of the pathogen in Spain and provided an accurate picture of population structure in the country at that time (Molinero-Ruiz et al., 2002, 2008).

Unfortunately, downy mildew outbreaks in resistant hybrids have become frequent in the last years and this was the case in Portugal. In the summer of 2016, symptoms of DM occurred in two fields in Fuentes de Andalucia (Spain) and Serpa (Portugal) where sunflower hybrids carrying both resistance genes $\mathrm{Pl}_{2}$ and $\mathrm{Pl}_{6}$ were grown. The pathogen was recovered from two samples (diseased sunflowers) from each location and molecularly identified by amplification of the nuclear DNA coding for the large ribosomal unit (28S rDNA) with LR0R and LR6-O primers (Riethmüller et al., 2002). Pathogenic traits were determined by artificial inoculation of the nine internationally accorded differentials of races (Gulya et al. , 1998). The four isolates resulted in clear resistant $(0 \%$ DM incidence) or susceptible ( $100 \% \mathrm{DM}$ incidence) reactions of the differentials. They were identified as race 705 , since they caused disease on HA304 (universal susceptible), RHA265 $\left(\mathrm{Pl}_{1}\right)$, and RHA274 $\left(\mathrm{Pl}_{2}\right)$ lines, as well as on HAR4 $\left(\mathrm{Pl}_{16}\right)$ and HA335 $\left(\mathrm{Pl}_{6}\right)$ (Miller and Gulya, 1991) lines (García-Carneros and Molinero-Ruiz, 2017).

Unexpected favourable conditions for DM development have occurred in Spain in the spring of 2018. Consequently, important outbreaks have been observed even in highly resistant hybrids. More than 30 samples of affected resistant hybrids collected in different locations have been recovered and characterized by inoculation of the nine differentials of races. As a result, races $305,311,313,315,711,712,714$ and 715 have been identified by our research group in 2018. These 


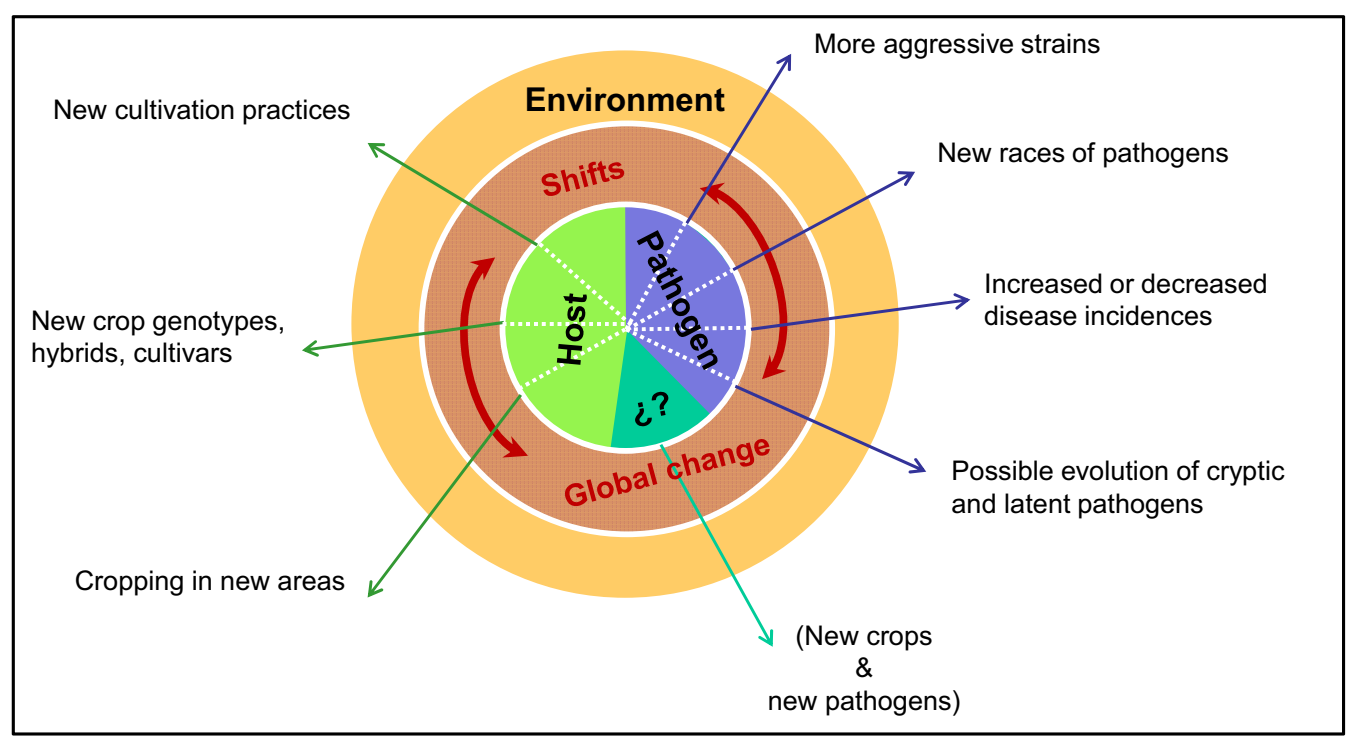

Fig. 1. Factors influencing disease occurrence related to host, pathogen and/or environment, that are subjected to shifts caused by climate change conditions.

results, which will be confirmed in future years, point to the shift in the pathogenic composition of $P$. halstedii populations in the area during the last 10 years. What is most remarkable of our work on monitoring and characterization of $P$. halstedii in the Iberian Peninsula is that it stresses the importance of identifying genes of resistance which can provide control of pathogen races of increasing virulence.

\subsection{Verticillium dahliae (Verticillium Wilt and Leaf Mottle)}

The mitosporic ascomycete Verticillium dahliae Kleb. causes chlorosis and yellowing near the leaf margin of sunflowers. Symptoms progress from the lower to upper leaves, which often appear mottled. Genetic resistance has been the most effective method for controlling Verticillium Wilt and Leaf Mottle (VWLM) in sunflower for nearly 50 years. Nonetheless, not very many sources of resistance have been reported, and there have been several reports of the fungus overcoming theses sources (Bertero de Romano and Vázquez, 1982; Gulya et al., 1997; Galella et al., 2004; Gulya, 2007; García-Ruiz et al., 2014).

Increases of sunflower Wilt diseases mostly associated to $V$. dahliae have been observed in countries of Europe like Bulgaria, France, Italy, Romania, Spain, Turkey and Ukraine in the last five or six years. Understanding and characterising the diversity of $V$. dahliae in those countries where sunflowers are frequent and severely affected by VWLM are essential for efficient breeding for resistance. Thus, analyses of the genetic, molecular and pathogenic traits of 36 isolates of $V$. dahliae affecting sunflowers in Europe, collected from infected fields between 2009 and 2016, were conducted by our research group. The methodology and results are summarized below. Extended information can be found in Martín-Sanz et al. (2018a).

The genetics of 36 monoconidial isolates was investigated by generation and characterization of nitrate non-utilizing (nit) mutants of each of them and determination of vegetative compatibility groups (VCGs) by pairings with complementary mutants of reference testers (Fig. 2). According to our results, most of the isolates from France, Italy, Spain, Argentina, and Ukraine were assigned to VCG2B. In Bulgaria, Turkey, Romania, and Ukraine, some isolates were assigned to VCG6, but others (11 of 19) could not be assigned to any VCG. This high proportion of isolates of unknown VCG suggested a higher genetic diversity of $V$. dahliae in Eastern Europe as compared to Western Europe.

Molecular traits of our collection were determined by means of genotyping markers used for $V$. dahliae affecting crops other than sunflower. They were developed for the identification of molecular races 1 (Usami et al., 2007; de Jonge et al., 2012) and 2 (Short et al., 2014), as well as for discrimination of defoliating (D) and non-defoliating (ND) pathotypes (Mercado-Blanco et al., 2001, 2002, 2003; Collado-Romero et al., 2009). Biomolecular analyses showed that all the isolates were molecularly identified as race 2 and that D and ND markers distinguished two well-differentiated clusters in our collection of $V$. dahliae (Fig. 3), although within them, isolates did not show very great similarities. One cluster (E) grouped isolates from Eastern Europe and the other (W) all those from the Western Europe and Argentina. Remarkably, all the isolates in cluster W were VCG2B, while the isolates in cluster E belonged to an unknown VCG or to VCG6.

The pathogenic behaviour of $V$. dahliae was investigated in two phenotyping experiments carried out in the greenhouse. Plants were inoculated by root immersion and incubated until they were 8-weeks old. VWLM was assessed by means of a Disease Index (DI) that was calculated as: $\mathrm{DI}=\mathrm{AN} \times \mathrm{SS}$, where AN is the percent of affected nodes and SS represents the severity of symptoms according to a $0-5$ scale based on leave symptoms. In addition to race V1 (controlled by the $\mathrm{V}_{1}$ gene into HA89), two additional pathogenic groups overcoming $\mathrm{V}_{1}$ were clearly distinguished: V2-EE (isolates of Eastern Europe) and V2-WE (isolates of Western Europe). Similarly, three differentials were identified for race 


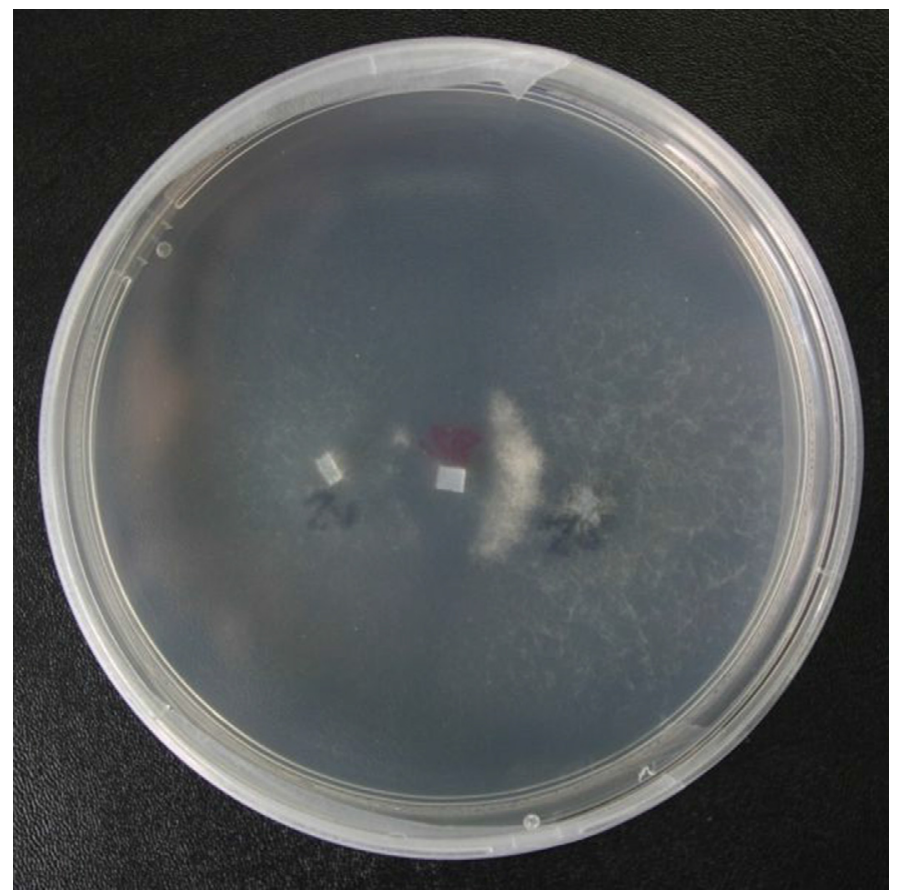

Fig. 2. Complementation between isolates of Verticillium dahliae from sunflower. Tester, placed in the centre of the plate, is paired to one isolate showing negative complementation (left) and another one showing positive complementation (right) and thus belonging to the same VCG as the tester.

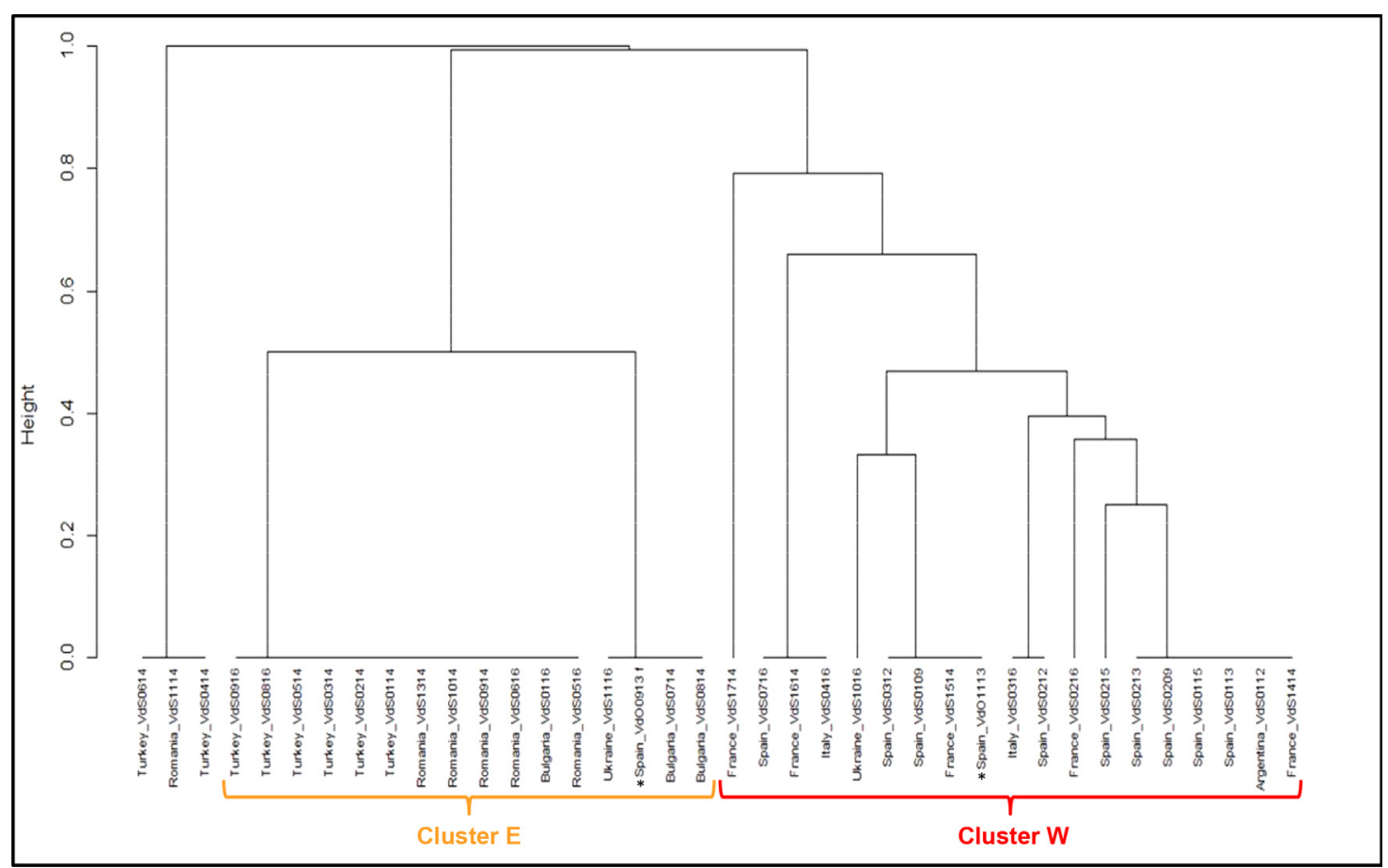

Fig. 3. UPGMA dendrogram based on data from molecular markers for 38 Verticillium dahliae isolates from sunflower and olive tree (marked with *). Adapted from Martín-Sanz et al. (2018a).

determination: HA 458 (universal susceptible), HA 89 (resistant to V2-EE, susceptible to V2-WE) and INRA2603 (susceptible to V2-EE, resistant to V2-WE) (Fig. 4). The most important outcomes of this research are that reverse reactions of resistance/susceptibility were shown by the public lines HA
89 and INR2603, which are frequently used as donors of resistance to VWLM; and that the existing pathogenic diversity of $V$. dahliae must be properly managed through the development of hybrids with resistance for specific geographical areas (Western and Eastern Europe). 


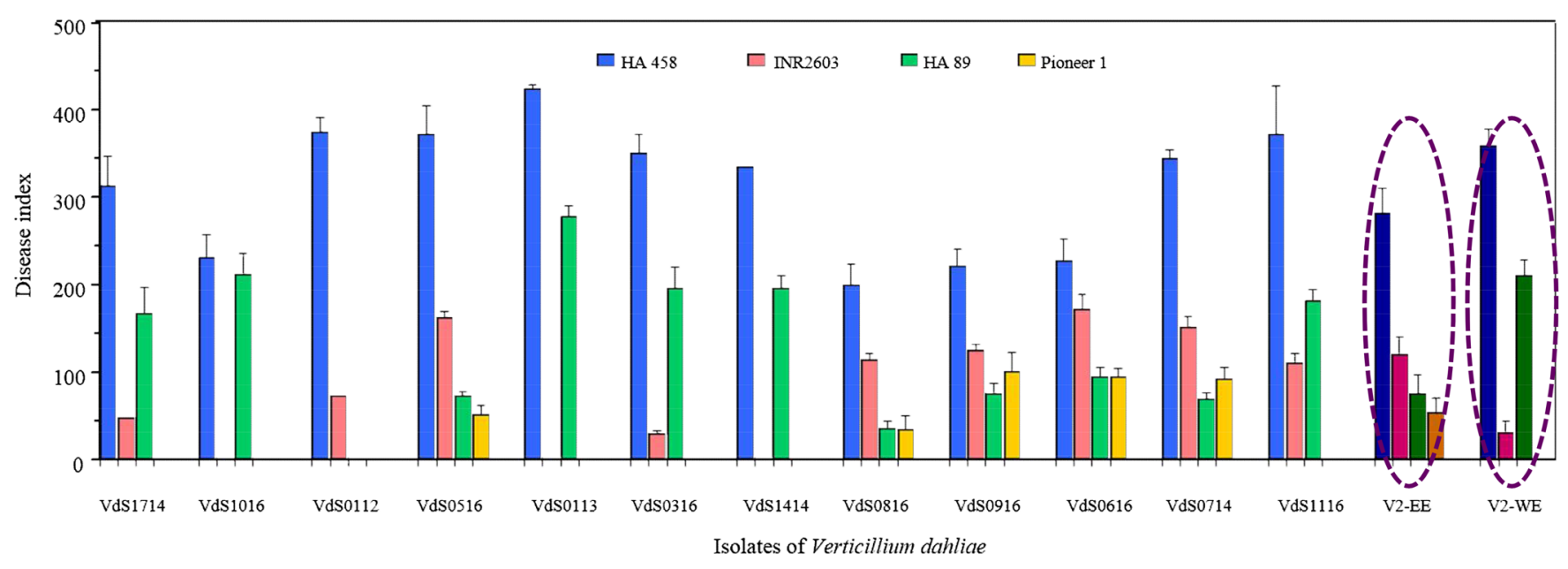

Fig. 4. Verticillium wilt and leaf mottle in four sunflower genotypes caused by 12 Verticillium dahliae isolates from different geographical origin expressed by a disease index (DI). The last two groups of darker bars marked with dashed line ovals represent DI values averaged for isolates from the east (V2-EE) and the west (V2-WE) of Europe. For information on particular geographical location of isolates, please see Martín-Sanz et al. (2018a). Bars with the same lower case letters are not significantly different according to the least significant difference test $(P=0.05)$. Adapted from Martín-Sanz et al. (2018a).

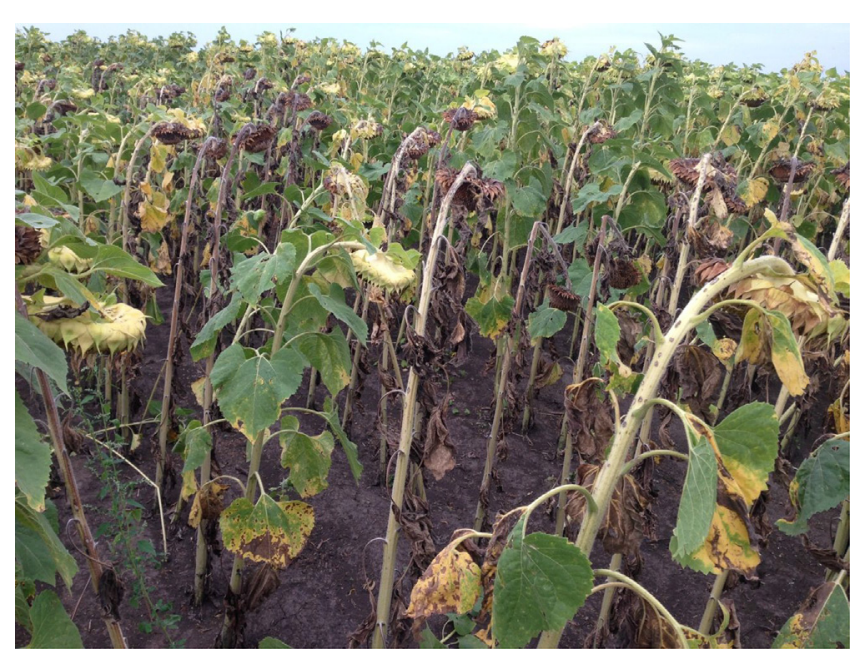

Fig. 5. Symptoms of leaf yellowing and necrosis, and sudden death caused by Cadophora malorum in a sunflower field (Martín-Sanz et al., 2018c).

\subsection{Cadophora malorum (Wilting, Yellowing and Leaf Necrosis)}

Wilted sunflowers were observed in two fields in Russia, one in Saratov in August 2015 and another in Orenburg in August 2016 (Fig. 5). In the summer of 2017, the same symptomatology occurred in sunflower fields in Ukraine (Kiev, Cherkasy and Mykolaiv oblasts) (Martín-Sanz et al., 2018b). Four basal stem samples from each field of Russia were disinfested, recovered onto water-agar medium and grown on potato dextrose agar (PDA) for morphological characterization and for obtaining fungal DNA. Flat colonies with felty to fleecy rings, the colour varying from white-beige to brown-olivaceous were consistently recovered (Fig. 6) and identified as a species of Cadophora (Schol-Schwarz, 1970). Samples of DNA were amplified using the $\beta$-tubulin locus primers BTCadF/BTCadR (Travadon et al., 2015) and molecularly confirmed as Cadophora malorum.

The pathogenicity of the fungus was confirmed in a greenhouse experiment. Three-week-old plants of the genotypes HA458 (public line) and DP1 (Dupont Pioneer) were independently inoculated, by root immersion, with the four fungal colonies. Roots of the control treatments were immersed in water. After incubation in pots for six weeks, symptoms developed in $100 \%$ of the plants of both genotypes. Wilting and dwarfism were observed in the inoculated plants and at least half of the nodes of those plants had necrotic leaves (Fig. 7). Water-inoculated plants did not show any symptom. Koch's postulates were completed by means of re-isolation of the fungus from basal stem tissues (Martín-Sanz et al., 2018c). Currently, a small collection of C. malorum pathogenic to sunflower and collected in different locations is maintained in the Laboratory of Field Crop Diseases at the Institute for Sustainable Agriculture from CSIC in Córdoba (Spain) (Tab. 1).

\section{Novel tools for disease management. Entomopathogenic fungi}

The implementation of IPM in the case of soilborne crop pathogens relies heavily on genetic resistance, particularly in the case of herbaceous crops like sunflower. Apart from being friendly to the environment, ad hoc breeding programs can effectively incorporate genes for resistance into plant material in a relatively short period of time (Fick and Miller, 1997). Genetic resistance against diseases of field crops can be complemented by cultural practices (adequate selection of sowing date, tillage/non-tillage practices, etc.), but these have limited enforceability and questioned feasibility under determinate crop conditions, thus needing to be smartly 


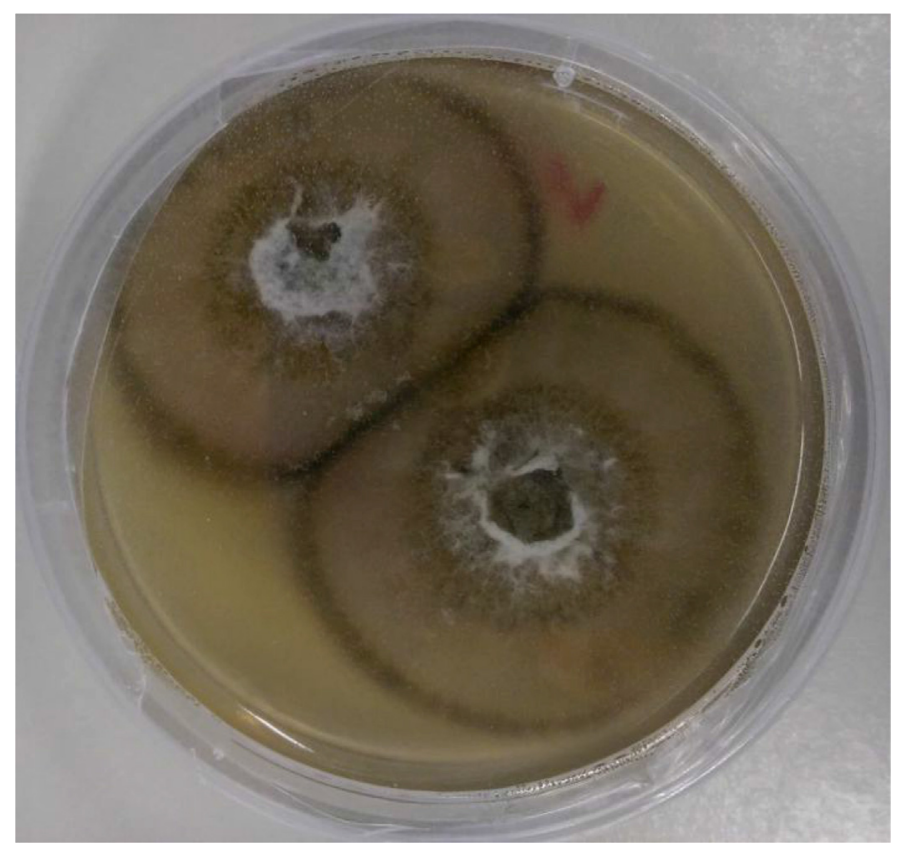

Fig. 6. Petri plate showing two colonies of the sunflower pathogen Cadophora malorum growing on potato dextrose agar medium. From MartínSanz et al. (2018b).
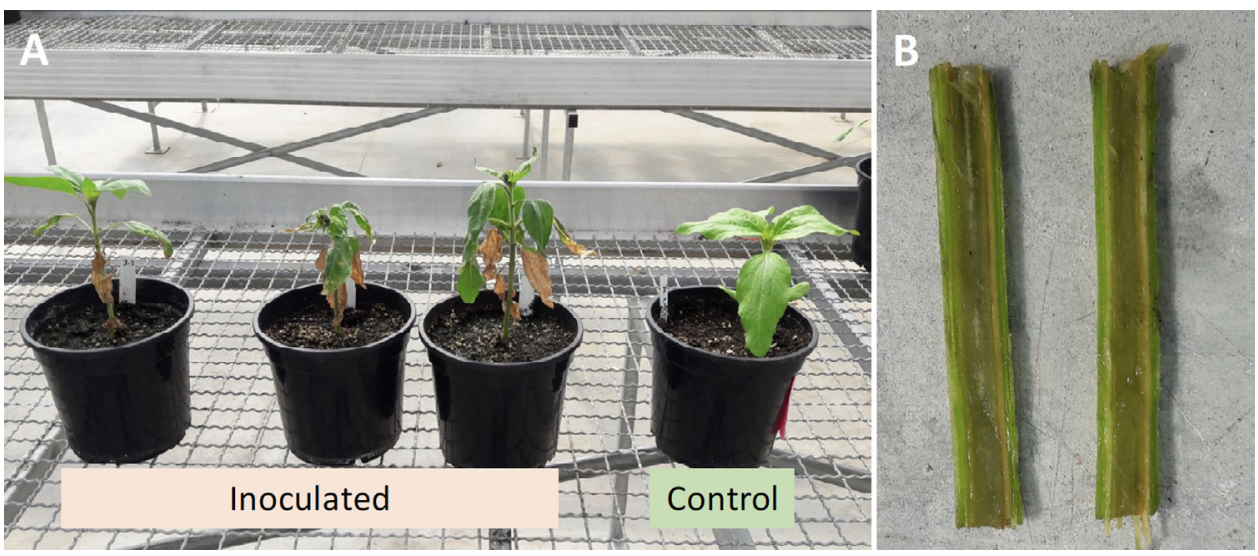

Fig. 7. Wilting and leaf necrosis in plants of the susceptible genotype HA458 five weeks after inoculation with Cadophora malorum (A) and longitudinal section of the stem showing vascular brownish coloration (B). Adapted from Martín-Sanz et al. (2018b).

Table 1. Collection of isolates of Cadophora malorum pathogenic to sunflower maintained in the Laboratory of Field Crop Diseases at the Institute for Sustainable Agriculture from CSIC in Córdoba (Spain).

\begin{tabular}{lllll}
\hline Reference & Year of collection & $\begin{array}{l}\text { Location } \\
\text { (Country, oblast) }\end{array}$ & Host plant & Ref. GenBank accession a \\
\hline CadoSR01-15 & 2015 & Russia, Saratov & Sunflower & MG458768 \\
CadoSR01-16 & 2016 & Russia, Orenburg & Sunflower, genotype 1 & MG458769 \\
CadoSR02-16 & 2016 & Russia, Orenburg & Sunflower, genotype 2 & MG458770 \\
CadoSR03-16 & 2016 & Russia, Orenburg & Sunflower, genotype 5 & MG458771 \\
CadoSU01-17 & 2017 & Ukraine, Kiev & Sunflower & Sunflower \\
CadoSU02-17 & 2017 & Ukraine, Cherkasy & Sunflower & \\
CadoSU03-17 & 2017 & Ukraine, Mykolaiv & &
\end{tabular}

\footnotetext{
${ }^{a}$ GenBank accession reported by Martín-Sanz et al. (2018c).
} 
tailored to different cropping systems (Bergstrom et al., 2008; Akhtouch et al., 2013; Molinero-Ruiz et al., 2015) which are themselves highly influenced by conditions of climate change conditions.

An attractive environmentally friendly alternative fight against crop pathogens is offered by allelopathic compounds (Farooq et al., 2011). Evidence for the antimicrobial activity of plant extracts and plant-derived compounds has accumulated over the last decade. In vitro experiments by our research group have shown the antifungal activity of Lycium europaeum extracts on the sunflower pathogens $V$. dahliae and Sclerotinia sclerotiorum, and even their effect against in reducing late wilt of maize was observed (Tej et al., 2018). Extracts of $L$. europaeum reduced the mycelial growth of both fungi and smaller numbers of sclerotia of $S$. sclerotiorum were formed. The hydroxycinnamic acid family of phenolics, including chlorogenic acid as a major compound, represented more than $50 \%$ of the total content in all the samples, and rutin was the most abundant flavonoid (Tej et al., 2018). This work highlights the potential of plant extracts (i.e. phenolic compounds) in crop protection if adequately developed into final products and used in combination with other tools.

Concerning biological control options, the deleterious effect of Pseudomonas spp. and Bacillus spp. against fungal pathogens and the micoparasitic potential of Fusarium oxysporum f. sp. orthoceras against broomrape were observed, although with low disease control levels (Hebbar et al., 1991; Thomas et al., 1998). Also working with Orobanche cumana Wallr., recent results by our research group have demonstrated that bacterization of sunflower seeds with Pseudomonas spp. can promote plant growth as well as result in significant reductions of the number of broomrape nodules (Gómez-Lama Cabanás et al., 2018), but this has not yet been implemented under field conditions.

Fungal endophytes have become an emerging area of research in plant pathology during the last two decades. They can foster the expression of defence mechanisms against diseases in plants and therefore have the potential to contribute as biocontrol agents in IPM (Arnold et al., 2003; Backman and Sikora, 2008; Zabalgogeazcoa, 2008; Ownley et al., 2010; Porras-Alfaro and Bayman, 2011; Khan et al., 2015; de Souza et al., 2016). Entomopathogenic fungi (EF) have been traditionally used in IPM strategies due to their efficacy in controlling insect pests affecting crops. In sunflower, research by our group has demonstrated the efficacy of EF on the control of wireworms (Agriotes spp.) (Coleoptera: Elateridae) (Ortiz-Bustos et al., 2016). Larvae of Agriotes sordidus naturally infected by the EF Metarhizium brunneum have been found in the field (Fig. 8). But many EF play unusual roles in nature, different from infection of insect pests, such as plant endophytes associating with the rhizosphere, plant growth promoting agents and even antagonists of plant pathogens (Vega et al., 2009). In particular, one of the most fascinating discoveries is that EF such as Beauveria bassiana and Lecanicillium spp., which for a long time were ecologically conceived as saprobes in soil, are natural endophytes in plants and can contribute to the suppression of diseases (Ownley et al., 2010).

Species such as M. brunneum and B. bassiana and some of their extracts have in vitro effect against plant pathogens (Vega et al., 2009; Lozano-Tovar et al., 2013, 2017) and

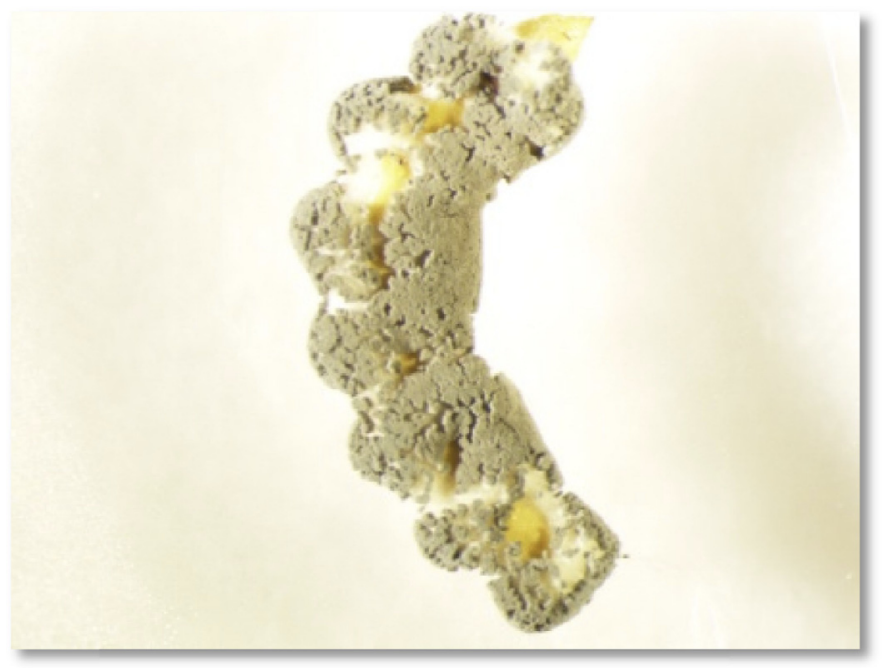

Fig. 8. Larva of Agriotes sordidus (wireworm) with sporulation of the entomopathogenic fungus Metarhizium brunneum.

even the reduction of the seedling disease caused by the seedborne Fusarium culmorum on wheat has been reported as associated with Metarhizium spp. (Keyser et al., 2016). Although the use of EF as plant endophytes providing protection against crop diseases is an emerging and outstanding research area for effective IPM strategies (Lacey et al., 2015), the role of these EF against soilborne pathogens and the diseases they cause in plants has not yet been addressed. Furthermore, and due to their natural presence in soils (Quesada-Moraga et al., 2007), EF show ecological requirements close to those of soilborne pathogens, which might contribute to their success in the protection of crops against these type of diseases.

Since EF they are consistent with the ideals of IPM strategies in sustainable agriculture, their unexplored role against soilborne pathogens affecting sunflower appears as a crucial research goal. In a recent work by our group dual cultures were carried out to challenge 10 isolates of $V$. dahliae and three of $C$. malorum against two strains of $B$. bassiana and three of M. brunneum. Active growing colonies of the pathogens and EF were confronted on Malt Extract Agar and incubated at $25^{\circ} \mathrm{C}$ in darkness. Four growth patterns were observed: no influence on growth, inhibition of the pathogen, inhibition of the EF, and growth of the EF strain over the pathogen. When the effect of EF on mycelial growth of $V$. dahliae and C. malorum was quantified, two strains of $M$. brunneum were interesting: one of them inhibited the growth of all the isolates of both pathogens and produced clear inhibition halos; the other overgrew all the pathogen colonies (Miranda-Fuentes et al., 2018). Operating mechanisms against sunflower pathogenic fungi suggested by our results, such as antibiosis or competition for ecological niche, are being investigated in depth. From a practical point of view, EF have the added value of potential use in alternation or in combination with genetic resistance into sunflower and, according to our results, they could constitute a novel tool in the development of IPM strategies that are effective against soil-borne pathogens of this crop. 
Acknowledgements. Research at the Laboratory of Field Crop Diseases at IAS-CSIC in Córdoba (Spain) supported by grants AGL2010-17909 and AGL2016-80483-R, from the Spanish Ministry of Economy, Industry and Competitiveness, and P12AGR-1281 from the Andalusian Government, co-financed by ERDF from the EU.

\section{References}

Akhtouch B, Molinero-Ruiz L, Dominguez J, Melero-Vara JM, Fernández-Martínez JM. 2013. Using sowing date modification and genetic resistance to manage sunflower broomrape (Orobanche cumana Wallr.). Helia 36(59): 17-34.

Arnold AE, Mejía LC, Kyllo D, et al. 2003. Fungal endophytes limit pathogen damage in a tropical tree. Proc Natl Acad Sci USA 100: 15649-15654.

Backman PA, Sikora RA. 2008. Endophytes: An emerging tool for biological control. Biol Control 46: 1-3.

Bebber DP. 2015. Range-Expanding Pests and Pathogens in a Warming World. Annu Rev Phytopathol 53: 335-56.

Bergstrom G, Leslie J, Huber D, et al. 2008. Recovery plan for late wilt of corn caused by Harpophora maydis syn. Cephalosporium maydis. National Plant Disease Recovery System (NPDRS), Homeland Security Presidential Directive No. 9, USA.

Bertero de Romano AB, Vázquez A. 1982. A new race of Verticillium dahliae Kleb. In: Proceedings of the 10th International Sunflower Conference, Toowoomba, QLD, pp. 177-178.

Chellemi DO, Gamliel A, Katan J, Subbarao KV. 2016. Development and deployment of systems-based approaches for the management of soilborne plant pathogens. Phytopathology 106(3): 216-225.

Collado-Romero M, Berbegal M, Jiménez-Díaz RM, Armengol J, Mercado-Blanco J. 2009. A PCR-based "molecular tool box" for in planta differential detection of Verticillium dahliae vegetative compatibility groups infecting artichoke. Plant Pathol 58: $515-526$.

de Jonge R, van Esse HP, Maruthachalam K, et al. 2012. Tomato immune receptor Ve1 recognizes effector of multiple fungal pathogens uncovered by genome and RNA sequencing. Proc Natl Acad Sci USA 109: 5110-5115.

de Souza JT, Trocoli RO, Monteiro FP. 2016. Plants from the Caatinga biome harbor endophytic Trichoderma species active in the biocontrol of pineapple fusariosis. Biol Control 94: 25-32.

Farooq M, Jabran K, Cheema ZA, Wahid A, Siddique KHM. 2011. The role of allelopathy in agricultural pest management. Pest Manage Sci 67: 493-506.

Fick GN, Miller JF. Sunflower breeding. In: Schneiter AA, ed. Sunflower Technology and Production. Madison WI (USA): ASA, CSSA, SSSA publishers, 1997.

Galella MT, Bazzalo ME, León A. 2004. Compared pathogenicity of Verticillium dahliae isolates from Argentine and the USA. In: Proceedings of the 16th International Sunflower Conference, Fargo, ND, pp. 177-180.

García-Carneros AB, Molinero-Ruiz L. 2017. First report of the highly virulent race 705 of Plasmopara halstedii (downy mildew of sunflower) in Portugal and in Spain. Plant Dis 101(8): 1555.

García-Ruiz R, García-Carneros AB, Molinero L. 2014. A new race of Verticillium dahliae causing leaf mottle of sunflower in Europe. Plant Dis 98(10): 1435.

Gómez-Lama Cabanás C, Mercado-Blanco J, García-Carneros AB, Molinero-Ruiz L. 2018. Beneficial bacteria from the olive rhizosphere promote growth of sunflower plants and reduce infection by Orobanche cumana. In: Proceedings of the
International Symposium on Confection Sunflower Technology and Production. Wu Yuan County, Inner Mongolia (China).

Gulya TJ. 2007. New strain of Verticillium dahliae in North America. Helia 30: 115-120.

Gulya TJ, Rashid KY, Marisevic S. Sunflower diseases. In: Schneiter AA, ed. Sunflower technology and production. Madison WI (USA): ASA, CSSA, SSSA publishers, 1997.

Gulya TJ, Tourvieille de Labrouhe D, Masirevic S, Penaud A, Rashid K, Virányi F. Proposal for standardized nomenclature and identification of races of Plasmopara halstedii (sunflower downy mildew). In Gulya T, Vear F, eds. ISA Symposium III Sunflower Downy Mildew. Fargo ND, 1998, pp. 130-136.

Hebbar P, Berge O, Heulin T, Singh SP. 1991. Bacterial antagonists of sunflower (Helianthus annuus L.) fungal pathogens. Plant Soil 133: 131-140.

Keyser CA, Jensen B, Meyling NV. 2016. Dual effects of Metarhizium spp. and Clonostachys rosea against an insect and a seed-borne pathogen in wheat. Pest Manage Sci 72: 517-526.

Khan AR, Ullah I, Khan AL, et al. 2015. Improvement in phytoremediation potential of Solanum nigrum under cadmium contamination through endophytic-assisted Serratia sp. RSC-14 inoculation. Environ Sci Pollut Res 22: 12114-12123.

Lacey LA, Grzywacz D, Shapiro-Ilan DI, Frutos R, Brownbridge M, Goettel MS. 2015. Insect pathogens as biological control agents: Back to the future. J Invertebr Pathol 132: 1-41.

Lozano-Tovar MD, Ortiz-Urquiza A, Garrido-Jurado I, TraperoCasas A, Quesada-Moraga E. 2013. Assessment of entomopathogenic fungi and their extracts against a soil-dwelling pest and soil-borne pathogens of olive. Biol Control 67: 409-420.

Lozano-Tovar MD, Garrido-Jurado I, Quesada-Moraga E, RayaOrtega MC, Trapero-Casas A. 2017. Metarhizium brunneum and Beauveria bassiana release secondary metabolites with antagonistic activity against Verticillium dahliae and Phytophthora megasperma olive pathogens. Crop Prot 100: 186-195.

Martín-Sanz A, Rueda S, García-Carneros AB, et al. 2018a. Genetics, host range, and molecular and pathogenic characterization of Verticillium dahliae from sunflower reveal two differentiated groups in Europe. Front Plant Sci 9: 288.

Martín-Sanz A, Rueda S, García-Carneros AB, Molinero-Ruiz L. 2018b. Cadophora malorum, a new threat for sunflower production in Russia and Ukraine. In: Proceedings of the International Symposium Sunflower and Climate Change, Toulouse (France), p. 52.

Martín-Sanz A, Rueda S, García-Carneros AB, Molinero-Ruiz L. 2018c. Cadophora malorum: A new pathogen of sunflower causing wilting, yellowing, and leaf necrosis in Russia. Plant Dis 102(4): 823.

Mercado-Blanco J, Rodríguez-Jurado D, Pérez-Artés E, JiménezDíaz RM. 2001. Detection of the nondefoliating pathotype of Verticillium dahliae in infected olive plants by nested PCR. Plant Pathol 50: 609-619.

Mercado-Blanco J, Rodríguez-Jurado D, Pérez-Artés E, JiménezDíaz RM. 2002. Detection of the defoliating pathotype of Verticillium dahliae in infected olive plants by nested-PCR. Eur J Plant Pathol 108: 1-13.

Mercado-Blanco J, Rodríguez-Jurado D, Parrilla-Araujo S, JiménezDíaz RM. 2003. Simultaneous detection of the defoliating and nondefoliating Verticillium dahliae pathotypes in infected olive plants by duplex, nested polymerase chain reaction. Plant Dis 87: 1487-1494.

Miller JF, Gulya TJ. 1991. Inheritance of resistance to race 4 of downy mildew derived from interspecific crosses in sunflower. Crop Sci 31: $40-43$. 
Miranda-Fuentes P, Quesada-Moraga E, Garrido-Jurado I, Molinero-Ruiz L. 2018. Insights into entomopathogenic fungi as an option against sunflower pathogens Verticillium dahliae and Cadophora malorum. In: Conference Proceedings of the International Symposium Sunflower and Climate Change, Toulouse (France), 57.

Molinero-Ruiz ML, Cordón-Torres MM, Martínez-Aguilar J, MeleroVara JM, Domínguez J. 2008. Resistance to metalaxyl and to metalaxyl-M in populations of Plasmopara halstedii causing downy mildew in sunflower. Can J Plant Pathol 30: 97-105.

Molinero-Ruiz ML, Dominguez J, Melero-Vara JM, 2002. Races of isolates of Plasmopara halstedii from Spain and studies on their virulence. Plant Dis 86(7): 736-740.

Molinero-Ruiz L, Delavault P, Pérez-Vich B, et al. 2015. History of the race structure of Orobanche cumana and the breeding of sunflower for resistance to this parasitic weed: a review. Span J Agric Res 13: e10R01a.

Ortiz-Bustos CM, Molinero-Ruiz L, Quesada-Moraga E, GarridoJurado I. 2016. Natural occurrence of wireworms (Coleoptera: Elateridae) and entomopathogenic fungi in sunflower fields of Spain, and evaluation of their pathogenicity toward wireworms. In: Abstract Book 49th Annual Meeting of the Society for Invertebrate Pathology, Tours (France), p. 109.

Ownley BH, Gwinn K, Vega FE. 2010. Endophytic fungal entomopathogens with activity against plant pathogens: ecology and evolution. Biocontrol 55: 113-128.

Porras-Alfaro A, Bayman P. 2011. Hidden fungi, emergent properties: endophytes and microbiomes. Annu Rev Phytopathol 49: 291-315.

Quesada-Moraga E, Navas-Cortés JA, Maranhao EAA, OrtizUrquiza A, Santiago-Álvarez C. 2007. Factors affecting the occurrence and distribution of entomopathogenic fungi in natural and cultivated soils. Mycol Res 111: 947-966.
Riethmüller A, Voglmayr H, Göker M, Weiß M, Oberwinkler F. 2002. Phylogenetic relationships of the downy mildews (Peronosporales) and related groups based on nuclear large subunit ribosomal DNA sequences. Mycologia 94: 834.

Short DPG, Gurung S, Maruthachalam K, Atallah ZK, Subbarao KV. 2014. Verticillium dahliae race 2 -specific PCR reveals a high frequency of race 2 strains in commercial spinach seed lots and delineates race structure. Phytopathology 104: 779-785.

Schol-Schwarz MB. 1970. Revision of the genus Phialophora (Moniliales). Persoonia 6: 59-94.

Schumann GL, D’Arcy CJ. 2010. Essential Plant Pathology. St Paul MN, USA: The American Phytopathological Society.

Tej R, Rodríguez-Mallol D, Rodríguez-Arcos R, Karray-Bouraoui N, Molinero-Ruiz L. 2018. Inhibitory effect of Lycium europaeum extracts on phytopathogenic soil-borne fungi and the reduction of late wilt in maize. Eur J Plant Pathol 152(1): 249-265.

Thomas H, Sauerborn J, Müller-Stöver D et al., 1998. The potential of Fusarium oxysporum f. sp. orthoceras as a biological control agent for Orobanche cumana in sunflower. Biol Control 13: $41-48$.

Travadon R, Lawrence DP, Rooney-Latham S, Gubler WD, Wilcox WF, Rolshausen PE, Baumgartner K. 2015. Cadophora species associated with wood-decay of grapevine in North America. Fungal Biol 119: 53-66.

Usami T, Ishigaki S, Takashina H, Matsubara Y, Amemiya Y. 2007. Cloning of DNA fragments specific to the pathotype and race of Verticillium dahliae. J Gen Plant Pathol 73: 89-95.

Vega FE, Goettel MS, Blackwell M et al., 2009. Fungal entomopathogens: new insights on their ecology. Fungal Ecol 2: 149-159.

Zabalgogeazcoa I. 2008. Review. Fungal endophytes and their interaction with plant pathogens. Span J Agric Res 6: 138-146.

Cite this article as: Molinero-Ruiz L. 2019. Recent advances on the characterization and control of sunflower soilborne pathogens under climate change conditions. OCL 26: 2. 